\title{
Book Review: Capital, State, Empire: The New American Way of Digital Warfare by Scott Timcke
}

\author{
Marc Kosciejew \\ University of Malta, Msida, Malta, mkosciej@gmail.com, \\ https://www.um.edu.mt/maks/las/staff/dr_marc_kosciejew
}

Abstract: Marc Kosciejew reviews Capital, State, Empire: The New American Way of Digital Warfare by Scott Timcke (2017; London: University of Westminster Press [ISBN: 978-1911534-36-5]).

In Capital, State, Empire: The New American Way of Digital Warfare, Scott Timcke presents an alarming account of digital capitalism and its aggressive, exploitative, and expansionist nature. Timcke examines the corrosive relationship between capital and constraint as it is digitally mediated by diverse information communication technologies. Using the radical political economy tradition to help frame his critique of digital capitalism, his "central proposition is that the totality of [American] imperial relations, both foreign and domestic, are geared towards accumulating value, and amongst other processes, come about through dispossession, extraction, and exploitation, themselves amplified by digital coercion that allow for unprecedented reach" (xv). He argues that digital capitalism is applied and exercised in ways that ensure American paramountcy on a planetary scale whilst also ensuring conducive conditions for capital accumulation and profit.

Timcke specifically concentrates on how American imperialism - comprised by a powerful American-centric capitalist system coupled with an increasingly militarised security apparatus - is facilitated and entrenched by these digital technologies through coercive digital practices that create structural injustices, stratifications, and inequalities. He further illuminates how these digital technologies have been co-opted, hijacked, usurped, and otherwise used by the (American) security apparatus to help enforce the capital system's control over society whilst "enabling the militarization in all aspects of social life, even areas that were once previously beyond the reach of state violence" (10). The American Department of Defence, in fact, "is the single biggest purchaser of information and communication goods" (xv). Digital capitalism, in other words, expands global capital accumulation efforts for ever-greater profits through coercive digital practices that ultimately result in dispossessing, extracting, and exploiting nearly everything it encounters or needs from individuals and communities to resources and countries.

The first chapter presents a robust materialist critique of digital society. This chapter is arguably the book's most important and illuminating theoretical intervention. Timcke explores digital rule through new and emerging labour regimes, such as the intellectual property regime, and the coercive practices with and uses of diverse kinds of data. He argues, for example, that the present intellectual property regime protects and promotes digital capitalism whilst it simultaneously undermines and guts labour. He also explains how data is the central component of the digital mode of production. He observes that "life is increasingly excessively mediated through data or platforms that harness data" (19); such data and data platforms are increasingly being used to profile, 
monitor, control, discipline, and commodify individuals. The goal is the datafication of everything; that is, transforming everything imaginable into forms or points of data that are, in turn, commodified and valued in terms of money and profit.

The second chapter outlines the main historical antecedents of capital and constraint's relationship in the formation of the American capitalist system and state. Timcke examines "the historical forces that create a path for uneven development in the US itself" (25) including dispossession, inter- and intra-class struggles, and changing labour regimes, with an emphasis on the centrality of violence in these processes. Sketching this historical overview of extraction, expansion, and economies of bondage, he shows the long-term relentless capitalist drive for accumulation and the ways in which the ruling American capitalist class has constantly adjusted, and continues to adjust, both state and security apparatuses to enforce its interests and in so doing maintain structural injustices and social stratification.

The third chapter discusses calculated computational conflict and digital warfare spearheaded by the American state and security apparatus. Timcke shows how the American security apparatus has militarised digital technologies to increase its force projection and entrench the imperial capitalist system around the world. He states that the US military deems digital technologies, specifically robotic instruments of war, as "crucial pieces of future military capacity, force, and planning" (60). Drones, for example, "have become a new indispensable battlefield technology with offensive capabilities" (60) despite evidence of civilian casualties, destruction, and, ultimately, the worsening of conditions and the creation of more and new enemies. Surveillance tools, meanwhile, enable the continuous gathering of personal information and monitoring of the general population in the United States and abroad. Timcke quotes former National Security Agency (NSA) directors' comments, such as "collect it all" and "we kill people based on metadata" (68), as emblematic of these militarised surveillance practices.

The fourth chapter addresses the American security apparatus's internal operations and patterns of subjugation that maintain social stratification. Timcke's focus is on police brutality, sanctioned by the state and facilitated through increasing militarisation of police services, practices, and behaviours. He argues that this militarisation facilitates "police using excessive, unreasonable, and unnecessary force, acting like a standing occupation army" (86) creating a climate of fear throughout society. He illuminates disturbing accounts of the "daily ugliness" (91) of police brutality, which is particularly targeted towards vulnerable minority and disadvantaged communities, revealing "the extent to which the US is a political order structured around violence" (91).

The fifth chapter addresses the American security apparatus's external operations that extend capitalist imperialism and, in so doing, enforce uneven development and creates conditions for (more) conflict. Timcke argues that the capitalist free trade regime is designed to install market economies and accelerate capital accumulation by opening trade routes to extract profits on American terms. He argues that American military power and presence, especially with international bases and special forces, are necessary to "further capital's extractive ends" (113) by securing the circuits and modes of production and pacifying or preventing opposition.

The sixth chapter analyses quantified cognitive behaviourism and the coercive ways in which it is used through digital technologies to further capitalist state rule. Timcke focuses on paternalistic nudges in which decontextualised "algorithmic regulation marries anticipatory adaption of the environment with the various kinds of [digital] technologies of surveillance such as dynamic biometrics and smart environments of those same environments to guide public interventions according to what particular people are susceptible to do" (134). He argues that these nudges influence individuals' actions 
and decisions to comply with preferred social actions, ultimately undermining their "agency that is foundational to the person-as-citizen. Rather, people are objectified" and "what is substituted is the perspective of the dominant order" (136). Most individuals, moreover, are unaware of these nudges because of these technological processes of mystification.

Capital, State, Empire offers a timely examination of the increasing militarisation of digital technologies and the ways in which they are being employed to further American-centric capitalism's drive for accumulation through expansion, dispossession, and exploitation. The book, at less than 200 pages, is a brief but sharp intervention for helping raise awareness of the often hidden, or, as Timcke describes it, "mystified" (51), digital coercion and its impacts on our lives. The arguments are also supported by relevant research from a rich variety of scholarly and public sources, which are compiled in a comprehensive reference list at the end.

The main criticism, however, is the lack of a clear connection between the book's six chapters. Although the main topic of the book - the relationship of capital to constraint - serves as the overall thematic framework, the chapters' concentrations seem somewhat disjointed, as though they are separate articles or pieces that have been collated together under this theme. The first chapter, for example, is arguably the strongest section, providing a detailed and insightful analytical critique of digital society. But this line of inquiry does not appear to continue or weave into the following chapters; instead, the second chapter breaks off into an historical overview of state formation, the third, fourth and fifth chapters discuss contemporary capitalist practices, and the sixth chapter delves into a dense theoretical discussion on quantified cognitive behaviourism. The transition between the fifth and sixth chapters is particularly jarring as it segues from a discussion on unequal and imbalanced free trade regimes directly into academic concepts in the social sciences. Each chapter, on its own, is illuminating; however, as a book, there does not appear to be a clear, unified approach. The book, in other words, gives more of an impression of an anthology of the author's ideas and work on this topic. The book's arguments and points are not necessarily diminished, but they would be strengthened by a more unified approach.

The book would also benefit from a closer edit. There are a number of grammatical and syntactical errors throughout the book that, although minor in and of themselves, have a cumulative impact that distracts from the content itself. These minor, but noticeable, mistakes could easily be rectified with more of a meticulous revision. It must be noted, however, that they do not necessarily undermine the book's many interesting ideas and points.

This book is nevertheless an important contribution to interdisciplinary studies involving communications, information science, political science, economics, and social science. It provides a useful foundation on which to pursue further examinations into the militarisation of digital technologies and society.

\section{About the Author}

Marc Kosciejew

Marc Kosciejew holds a PhD in Library and Information Science from Western University in London, Ontario, Canada. He is presently a Lecturer and previous Head of Department of Library, Information, and Archive Sciences at the University of Malta in Msida, Malta. He was appointed by Malta's Minister for Education and Employment as Chairperson of the Malta Libraries Council (MLC), a government-appointed national council stipulated in the Malta Libraries Act, 2011, to provide strategic advice to the National Library of Malta and public library 
system. His research interests concentrate on documentation studies, philosophy of information, records and information management, and the intersections of information, institutions, and individuals. 